structure requires correction, since it assumes that the atomic nucleus contains electrons, and it is doubtful whether the circular diagrams of atoms are the most suitable for explanations of valency. It is questionable whether adsorption should be introduced into the section on solutions. The sections on solutions and electrolysis are very good, and give an adequate account of the subjects; that on catalysis is rather old-fashioned, and the reactions given on p. 213 for the lead chamber reactions would be more accurate if water were introduced into the first.

A good feature of the book is the emphasis laid on numerical calculations, and the excellent series of problems given at the ends of the chapters will be very helpful on this side. The book is one which should prove useful both to junior students and to teachers.

\section{Geography and Travel}

\section{Physiography of Eastern United States}

By Prof. Nevin M. Fenneman. Pp. xiii $+714+7$ plates. (London and New York: McGraw-Hill Book Co., Inc., 1938.) 36s.

$\mathrm{T}$ HE equivalent in Great Britain of the term physiography is geomorphology, and that is the content of this book. It is planned and written on the same lines as the author's volume on the Western United States which was published seven years ago. The area now covered stretches westward across the Mississippi basin to the edge of the High Plains. It is a massive book, full of detail, arranged under the provinces which in America are the generally accepted physical divisions. As a whole these are the divisions of the country accepted by the United States Geological Survey.

The material available to the author was abundant, though of varying value in different provinces. $\mathrm{He}$ has tried, and with a large measure of success, to produce something more than a mere compilation of details. There is certainly much purely descriptive matter, but the broad issues of geomorphological evolution are never lost to view. One might, however, wish for a chapter or two of general summary for those who have not time for the fuller treatment. The book is fully documented on every page and has a number of maps.

\section{Northernmost Labrador Mapped from the Air}

By Alexander Forbes, with Contributions by O. M. Miller, N. E. Odell and Ernst C. Abbe. (American (Geographical Society Special Publication No. 22.) Pp. $x x+255$. Navigational Notes on the Labrador Coast. By Alexander Forbes. Pp. $26+6$ plates. (New York : American (Keographical Society, 1938.) 4 dollars.

$7 \mathrm{HE}$ greater part of this book contains accounts of aerial surveys made in Northern Labrador in the summers of 1931, 1932 and 1935. Previous maps of that part of Labrador were vague and generalized on the whole, although some of the inlets had been charted. Details of the organization, equipment and methods are given with much general information about the country. The methods are fully described by
Mr. O. M. Miller. The net result was a map of some 4,000 square miles extending from Nachvak fjord to Cape Chidley, most of which is produced on a scale of $1: 100,000$. The sheets accompany the monograph in a separate cover. In addition to this side of the work the volume contains a number of other useful articles, including one by Mr. N. E. Odell on the geology and physiography, and another by Mr. E. C. Abbe on phytogeographical observations, and a separate pamphlet of Navigational Notes on the Labrador Coast by Mr. A. Forbes. The flora of the higher mountains contains many of the same species as the nunataks of Greenlend. These Dr. Abbe regards as the hardiest members of the flora, but he does not believe that they survived through the last glaciation on nunataks, which Mr. Odell in any case does not think existed. He favours the hypothesis of relatively rapid migration northward in a past glacial optimum. Subsequent refrigeration may have resulted in a shrinking of the distributional areas of these species.

The volume contains a large number of fine photographs illustrating every aspect of the work.

\section{The South}

Its Economic-Geographic Development. By A. E. Parkins. Pp. ix +528. (New York : John Wiley and Sons, Inc. ; London : Chapman and Hall, Ltd., 1938.) 25s. net.

$7 \mathrm{HE}$ title of this book refers to the sixteen States in the south-east of America from Delaware and Maryland westward to Oklahoma and Texas. This area covers a great deal more than the plains of the south-east and the cotton belt since it embraces much of the Appalachian uplands, but is nevertheless a fairly well-defined region on economic and cultural grounds. Mr. Parkins attempts to give a survey of this area leading from physical factors and historical records to the present geographical and economic conditions. In short, he is concerned with an interpretation of life as it exists to-day, in a region that is primarily agricultural but in which agriculture is changing in aspect and intensity and where mining and manufactures are beginning to play an important part. The book, which is well documented and has abundant maps and illustrations, is a valuable contribution to the geography of the United States, and is, moreover, a good example of geographical reasoning.

R. N. R. B.

\section{Engineering}

\section{Carburettors and Fuel Systems}

The Theory, Application, Construction, Fitting, Testing, Tuming and Maintenance of Carburettors and other Fuel Combustion Devices. By Arthur W. Judge. (Motor Manuals: a Series for all Motor Ownors and Users, Vol. 2.) 'Third and revised edition. Pp. 362. (London: Chapman and Hall, Ltd., 1938.) 6s. net.

HIS, the second volume in a series of four motor
manuals which have proved very popular, has
now reached the stage of being issued in a third 